\title{
Calcium Electrotransfer for Termination of Transgene Expression in Muscle
}

\author{
Pernille Hojman,, ${ }^{1,2}$ Iben Spanggaard, Caroline Holkman Olsen, ${ }^{3}$ Julie Gehl, and Hanne Gissel ${ }^{4}$
}

\begin{abstract}
Gene electrotransfer is expanding in clinical use, thus we have searched for an emergency procedure to stop transgene expression in case of serious adverse events. Calcium is cytotoxic at high intracellular levels, so we tested effects of calcium electrotransfer on transgene expression in muscle. A clinical grade calcium solution $(20 \mu \mathrm{l}, 168 \mathrm{mM})$ was injected into transfected mouse or rat tibialis cranialis muscle. $\mathrm{Ca}^{2+}$ uptake was quantified using calcium $45\left({ }^{45} \mathrm{Ca}\right)$, and voltage and time between injection and pulsation were varied. Extinction of transgene expression was investigated by using both in vivo imaging of infrared fluorescent "Katushka" and erythropoietin evaluated by ELISA and hemoglobin. Histology was performed. Electrotransfer of Katushka and erythropoietin yielded significant expression. Maximal calcium uptake occurred after injection of $\mathrm{Ca}^{2+}$ before electropulsing using eight high voltage pulses of $1000 \mathrm{~V} / \mathrm{cm}$. Using these parameters, in vivo imaging showed that transgene expression significantly decreased $4 \mathrm{hr}$ after $\mathrm{Ca}^{2+}$ electrotransfer and was eliminated within $24 \mathrm{hr}$. Similarly, serum erythropoietin was reduced by $46 \%$ at $4 \mathrm{hr}$ and to control levels at 2 days. Histological analyses showed muscle damage and subsequent regeneration. Electrotransfer of isotonic $\mathrm{CaCl}_{2}$ terminates transgenic protein expression in muscles and may be used for contingency elimination of transgene expression.
\end{abstract}

\section{Introduction}

G ENE THERAPY OFFERS THE PROMISE of entirely new treatment strategies for a number of diseases. Examples from clinical trials include strategies to ameliorate consequences of genetic diseases such as adenosine deaminase deficiency (Kohn, 2010) or Leber's congenital amaurosis (Bainbridge et al., 2008; Maguire et al., 2008), and the over 1500 hundred trials registered are evidence of enthusiasm about this new treatment modality (http://clinicaltrials.gov). Several important aspects are being addressed, including methods to control gene expression, delineation of transfection site, and immunogenicity towards the transfection vector. A very interesting question is how to control gene expression once the gene therapy has been administered. To this end, several approaches have been suggested in particular inducible promoter systems, e.g., the Tet-On system (Gossen et al., 1995) and the GeneSwitch system (Nordstrom, 2003). To our knowledge no methods for complete elimination of transgene expression have been proposed.
One efficient way of transfecting genes into muscle tissue is DNA electrotransfer (Aihara and Miyazaki, 1998; Mathiesen, 1999; Mir et al., 1999). This method utilizes short electric pulses to transiently permeabilize cell membranes, rendering the cells accessible for plasmid DNA. This method distinguishes itself from other transfection methods like viral or liposomal therapies in that the transfection only takes place in the tissue encompassed by the electrodes delivering the electric field (Gehl, 2003). Thus the transfected area can be precisely localized following the treatment for any post-transfection intervention. Great efforts have been put into optimizing DNA electrotransfer so that the method itself causes as little disturbance to the muscle tissue as possible (Hojman et al., 2007c, 2008), and low level of tissue damage is induced when DNA electrotransfer is performed accordingly.

Therapeutic use of DNA electrotransfer to muscle tissue involves vaccination purposes, systemic delivery of therapeutic proteins, and local intramuscular expression. The clinical advances have so far been made within DNA vaccines to muscle tissue with seven on-going clinical trials

\footnotetext{
${ }^{1}$ Department of Oncology, Copenhagen University Hospital Herlev, DK-2730 Copenhagen, Denmark.

${ }^{2}$ Centre of Inflammation and Metabolism, Copenhagen Muscle Research Center, Rigshospitalet, DK-2100 Copenhagen, Denmark.

${ }^{3}$ Department of Pathology, Copenhagen University Hospital Herlev, DK-2730 Copenhagen, Denmark.

${ }^{4}$ Department of Physiology and Biophysics, University of Aarhus, DK-8000 Aarhus, Denmark.
} 
(Heller and Heller, 2006; Hojman, 2010), but muscle electrotransfer also holds great clinical promise for systemic delivery of therapeutic proteins, e.g., for protein deficiency syndromes and cancer treatment. Muscle tissue has a large capacity to produce and secrete protein and may function as a protein factory for systemic delivery (Lu et al., 2003). DNA electrotransfer to muscle tissue has proven to be highly efficient, resulting in systemic therapeutic levels of the transgenic product (Aihara and Miyazaki, 1998; Bettan et al., 2000; Lucas and Heller, 2001; Draghia-Akli et al., 2003; Fattori et al., 2005; Hojman et al., 2007b). Thus, a small volume of muscle tissue may be used to obtain systemic concentrations of protein.

We have speculated that if systemically therapeutic levels of transgene expression can be achieved by electrotransfer to just a small area of muscle (Hojman et al., 2007b), then it would be possible to extinguish this transgene expression by eliminating this small area of transfected muscle tissue. We have previously tried injections of cytotoxic compounds like $100 \%$ ethanol, but this was not successful in eliminating or even reducing the transgene expression (data not published). Others have suggested injections of bupivicaine, which is known to induce muscle necrosis and regeneration in the injected area with alterations in the gene expression pattern in the regenerated muscle (Clark et al., 1997). After pulse administration muscle cells are in a permeabilized state for a matter of minutes (Bier et al., 1999; Gehl et al., 2002). During this time, exchange of electrolytes across the plasma membrane takes place (Gissel, 2010; Hojman et al., 2008); notably, there is an inward flux of $\mathrm{Na}^{+}$and $\mathrm{Ca}^{2+}$ and an outward flux of $\mathrm{K}^{+}$. After membrane resealing, homeostasis is restored. Since a high concentration of $\mathrm{Ca}^{2+}$ has a cytotoxic effect, it may be possible to use electrotransfer of $\mathrm{Ca}^{2+}$ as a method to eliminate the transgene expression, and this can serve as a simple contingency solution in case of unwanted side effects of the gene therapy.

\section{Materials and Methods}

\section{Animals and muscle preparation}

All animal experiments were conducted in accordance with the recommendations of the European Convention for the Protection of Vertebrate Animals used for Experimentation and with permission from the Danish Animal Experiments Inspectorate. Animal experiments were performed on 8- to 10-week-old female C57Black/C or NMRI mice from Taconic or 4- to 8-week-old Wistar rats. The animals were maintained in a thermo-stated environment under a 12-hr light/dark cycle with free access to food and drinking water.

\section{Plasmid constructs and in vivo DNA electrotransfer}

The plasmids encoding genes of interest included pHDmEPO encoding murine EPO under the control of an rtTAdependent promoter (Hojman et al., 2007b) and pCMV-Kat encoding the far-red fluorescent protein Katushka (Kat) (Evrogen). The plasmids pTet-On, encoding the rtTA transactivator, and pTetS, encoding the $\mathrm{tS}$ silencer, were both obtained from Clontech. All DNA preparations were performed using Qiafilter Plasmid Maxiprep kits (Qiagen), and the concentration and quality of the plasmid preparations were verified by spectrophotometry and gel electrophoresis.
The animals were anesthetized $15 \mathrm{~min}$ prior to DNA electrotransfer by intraperitoneal injection of Hypnorm $(0.4 \mathrm{ml} / \mathrm{kg}$, Janssen Saunderton) and Dormicum $(2 \mathrm{mg} / \mathrm{kg}$, Roche). The plasmid solution ( $1.5 \mu \mathrm{g}$ in mice and $2 \mu \mathrm{g}$ in rats in $20 \mu \mathrm{l}$ ) was injected intramuscularly along the fibers into the tibialis cranialis muscle using a 29-gauge insulin syringe. Plate electrodes with a 4-mm gap in mice and a 6-mm gap in rats were fitted around the hind legs. Good contact between the electrode and skin was ensured by hair removal and use of electrode gel. DNA electrotransfer was performed using a combination of a high voltage $(\mathrm{HV} ; 800 \mathrm{~V} / \mathrm{cm}$ [applied voltage $=320 \mathrm{~V}$ in mice, $480 \mathrm{~V}$ in rats], $100 \mu \mathrm{sec}$ ) pulse followed by a low voltage $(\mathrm{LV} ; 100 \mathrm{~V} / \mathrm{cm}$ [applied voltage $=40 \mathrm{~V}$ in mice, $60 \mathrm{~V}$ in rats], $400 \mathrm{msec}$ ) pulse (Cliniporator) with volts per centimeter being the voltage to distance between the two plate electrodes. Induction of gene expression was obtained by administering drinking water containing doxycycline (doxycycline hyclate, Sigma-Aldrich) at $0.2 \mathrm{mg} / \mathrm{ml}$ in distilled water (Hojman et al., 2007a).

\section{$\mathrm{Ca}^{2+}$ electrotransfer}

$\mathrm{Ca}^{2+}$ injection solution $(9 \mathrm{mg} / \mathrm{ml}, 225 \mathrm{mM}$, Sandox) approved for clinical use was diluted to $168 \mathrm{mM}$ with sterile water, and 20-30 $\mu \mathrm{l}$ was injected into the tibialis cranialis. Electrotransfer was performed as described in the previous section by using eight pulses with a duration of $100 \mu \mathrm{sec}$, at $1000 \mathrm{~V} / \mathrm{cm}$ (applied voltage $400 \mathrm{~V}$ in mice, $600 \mathrm{~V}$ in rats), delivered at a frequency of $1 \mathrm{~Hz}$.

\section{Calcium 45 electrotransfer}

Calcium $45\left({ }^{45} \mathrm{Ca}\right)$ was added to the $168 \mathrm{mM} \mathrm{Ca}{ }^{2+}$ solution, resulting in a final activity of $0.5 \mu \mathrm{Ci} / \mathrm{ml}$. Twenty microliters was injected before, after, or both before and after (thus $40 \mu \mathrm{l}$ in total) placement of electrodes and pulse application $\left(\mathrm{Ca}^{2+}+\mathrm{EP}\right)$. Electrotransfer was performed as described by using eight pulses of $100-\mu$ sec duration, delivered at a frequency of $1 \mathrm{~Hz}$ at increasing pulse amplitudes. At the times given the animals were killed and the tibialis cranialis muscle was excised, weighed, and soaked overnight in $2.5 \mathrm{ml}$ of $0.3 \mathrm{M}$ trichloroacetic acid (TCA). ${ }^{45} \mathrm{Ca}$ activity of the TCA extract was determined by liquid scintillation counting (Tricarb2100 TR, Packard). Results are expressed as counts per minutes per gram of tissue (CPM/g wet wt.).

\section{Blood analyses}

In mice, blood samples $(20 \mu \mathrm{l})$ were drawn from the retroorbital sinus and hemoglobin levels were measured from a drop of blood using the HemoCue Hb201 + (HemoCue AB). At the termination of the experiments, $500 \mu \mathrm{l}$ of blood was drawn from the mice by cardiac puncture and processed to serum. In rats, blood samples $(200 \mu \mathrm{l})$ were drawn from the tail vein at the indicated time points. A drop was used for determination of hemoglobin and the rest was processed to serum. A Mouse/Rat Erythropoietin ELISA kit (RnD Systems) was used to determine erythropoietin (EPO) serum levels.

\section{In vivo bio-imaging}

Mice were anesthetized and placed in a custom-made bed, which allowed stable and reproducible imaging of the legs. 
In vivo scanning was performed using the Optix MX-2 Optical Molecular Image System (Advanced Research Technologies), which uses time domain optical imaging, allowing for quantitative determination of emission in the region specific to the Kat protein. Kat excitation was performed with a 635-nm (LDH-P-635) pulsing laser and emission was detected with a 650 long pass filter. The scan was performed over a Cartesian grid in prioritized raster fashion with 1-mm resolution, and each scan took $5 \mathrm{~min}$ on average. Data analysis was performed using the Optiview 2.2 software performing background subtraction, intensity measurements, and lifetime analysis of the fluorochromes. Lifetime values are reported as means of lifetimes in the gated transfected areas.

\section{Histology}

Twenty-four hours or 2 weeks after $\mathrm{Ca}^{2+}$ electrotransfer, muscles were isolated and fixed in $1 \mathrm{ml}$ formalin buffer. After paraffin embedding, transverse sections of $2 \mu \mathrm{m}$ were prepared and stained with hematoxylin and eosin (HE).

\section{Statistics}

Two-way ANOVA with ad hoc Bonferroni post-tests was performed to determine significant differences between treatment groups and time points, and $p<0.05$ was considered statistically significant.

\section{Results}

\section{${ }^{45} \mathrm{Ca}$ uptake in muscles after electrotransfer}

To determine the conditions for maximal $\mathrm{Ca}^{2+}$ influx with combinations of $\mathrm{Ca}^{2+}$ injection $\left(20 \mu \mathrm{l}\right.$ of $\left.168 \mathrm{mM} \mathrm{CaCl}_{2}\right)$ and electroporation, we tested ${ }^{45} \mathrm{Ca}$ uptake in mouse muscle injected with $\mathrm{Ca}^{2+}$ before, after, or both before and after electroporation. Injection of $\mathrm{Ca}^{2+}$ before electroporation increased ${ }^{45} \mathrm{Ca}$ uptake sevenfold $(p<0.001)$, while injection of ${ }^{45} \mathrm{Ca}$ after electroporation had smaller effect with a 2.3-fold increase in $\mathrm{Ca}^{2+}$ influx $(p<0.01)$. Injecting ${ }^{45} \mathrm{Ca}$ both before and after electroporation did not induce additional increases in the ${ }^{45} \mathrm{Ca}$ uptake compared to injection before electroporation, even though the received the double amount of $\mathrm{Ca}^{2+}$ (Fig. 1A).

We tested the voltage dependency of $\mathrm{Ca}^{2+}$ uptake and found a significant increase in $\mathrm{Ca}^{2+}$ uptake at pulse amplitudes above $500 \mathrm{~V} / \mathrm{cm}$, reaching a plateau in $\mathrm{Ca}^{2+}$ uptake at $1000 \mathrm{~V} / \mathrm{cm}$ (Fig. 1B). In these muscles, we also determined the water content and found that this increased from pulse amplitudes above $300 \mathrm{~V} / \mathrm{cm}$ and reached a plateau at $700 \mathrm{~V} /$ $\mathrm{cm}$ (Fig. 1C). Based on these results, we decided to use eight pulses $(100 \mu \mathrm{sec})$ of $1000 \mathrm{~V} / \mathrm{cm}$ with $\mathrm{Ca}^{2+}$ injection before the application of the electric pulses for $\mathrm{Ca}^{2+}$ electrotransfer.

\section{Termination of Kat expression}

To evaluate if $\mathrm{Ca}^{2+}$ electrotransfer could terminate transgene expression, muscles from mice were transfected with the far-red fluorescent molecule Kat and fluorescence was followed by in vivo imaging. Four days after Kat electrotransfer, all muscles had a clear Kat signal with mean intensity of $3305 \pm 464 \mathrm{NC}$ and mean lifetime of $2.04 \pm 0.01 \mathrm{nsec}(N=25)$. The muscles were then treated with $\mathrm{Ca}^{2+}$ electrotransfer, $\mathrm{Ca}^{2+}$
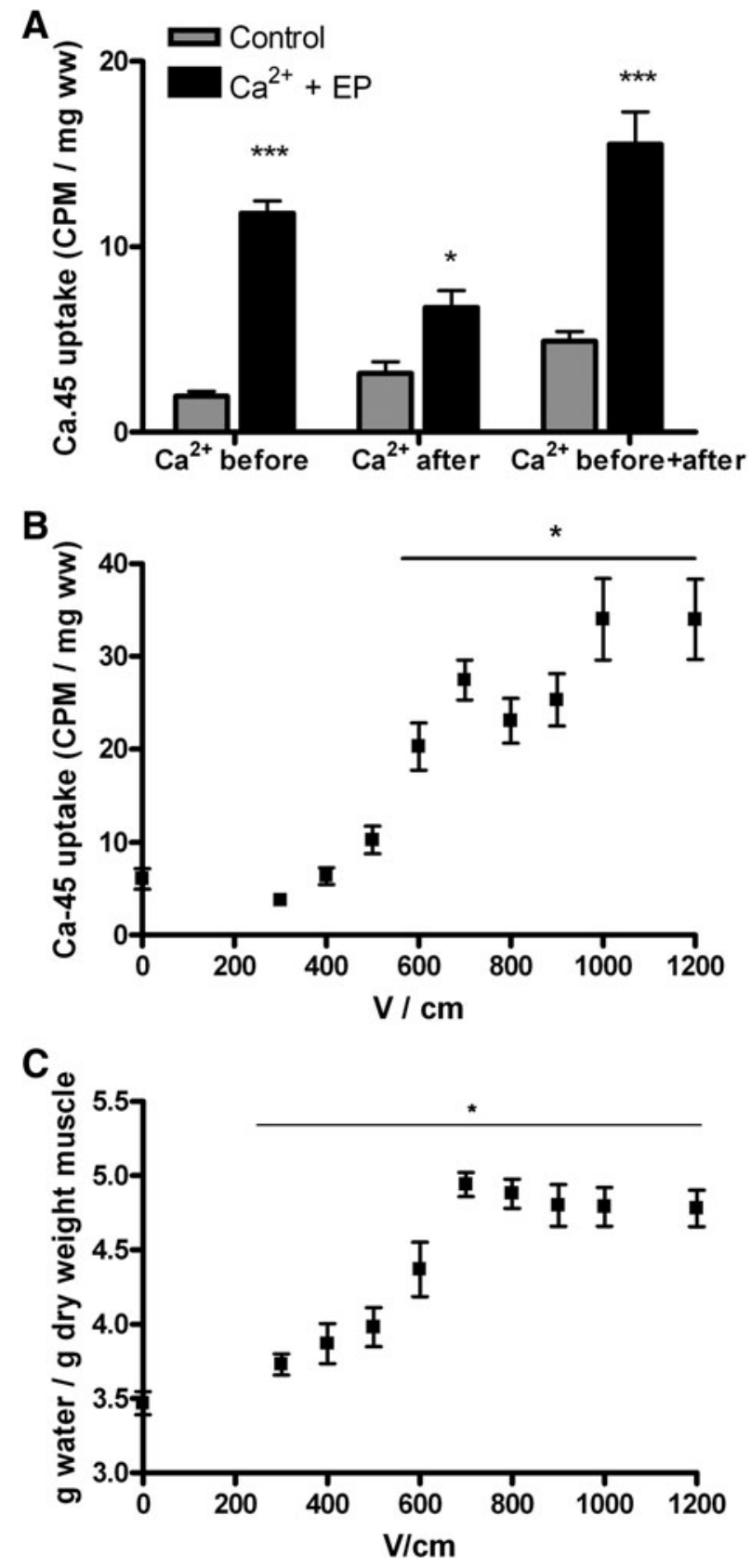

FIG. 1. Calcium influx in muscles during electroporation (EP). Combinations of $\mathrm{Ca}^{2+}$ injection $\left(20 \mu \mathrm{l}\right.$ of $168 \mathrm{mM} \mathrm{CaCl} \mathrm{m}_{2}$ with $0.5 \mu \mathrm{Ci}{ }^{45} \mathrm{Ca}$ ) and $\mathrm{EP}$ were tested. (A) Effect of injection timing: gray bars indicate $\mathrm{Ca}^{2+}$ injection only, while black bars represent $\mathrm{Ca}^{2+}$ injection and EP. In the before and after group, the mice were injected with $20 \mu \mathrm{l}$ both before and after EP. Statistical significance was tested by two-way ANOVA with ad hoc Bonferroni $t$-tests. ${ }^{*} p<0.05$ and ${ }^{* * *} p<0.001$. (B) Voltage-dependency of $\mathrm{Ca}^{2+}$ uptake with $\mathrm{Ca}^{2+}$ injection before EP, and (C) water content of the muscles from B. For B and C, statistical significance was tested by one-way ANOVA. $N=8,{ }^{*} p<0.05$.

injection only, electroporation only, or no treatment (control) (Figs. 2 and 3). In the $\mathrm{Ca}^{2+}$ electrotransfer-treated muscles, fluorescence intensity dropped significantly $(p<0.05)$ already $4 \mathrm{hr}$ after treatment and remained significantly reduced at the level of untransfected muscles from $24 \mathrm{hr}$ and at the following 

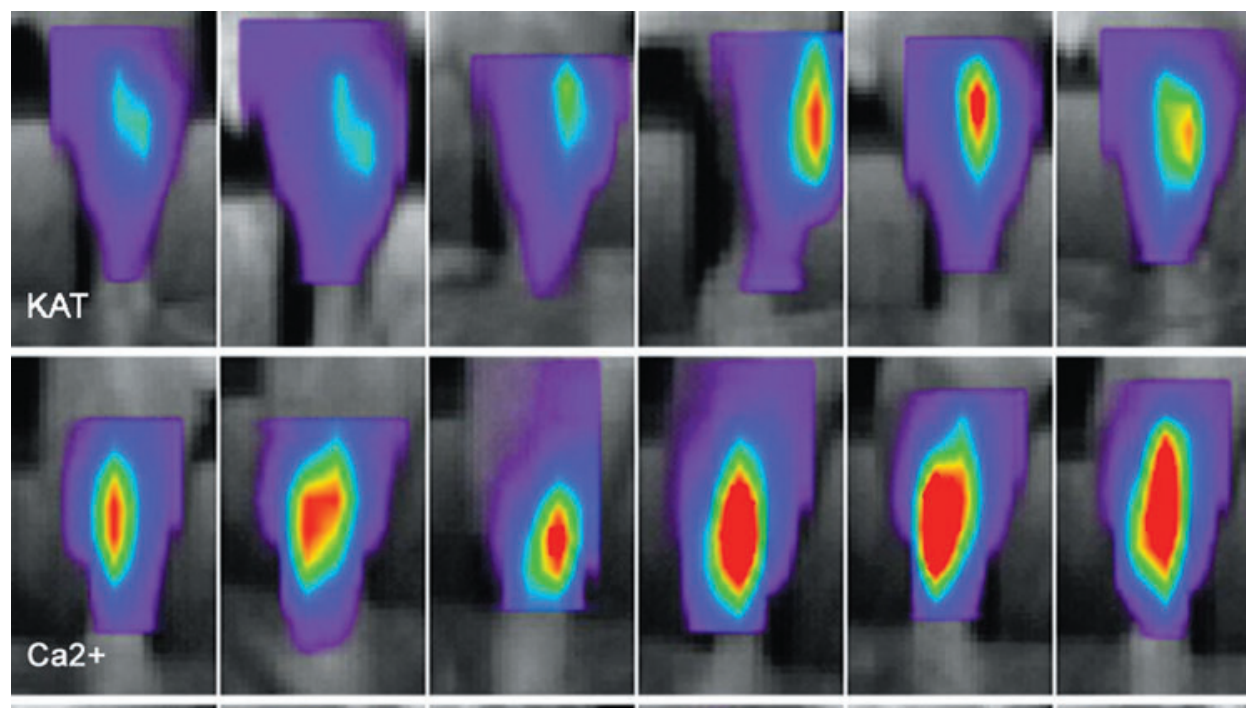

Intensity(NC)
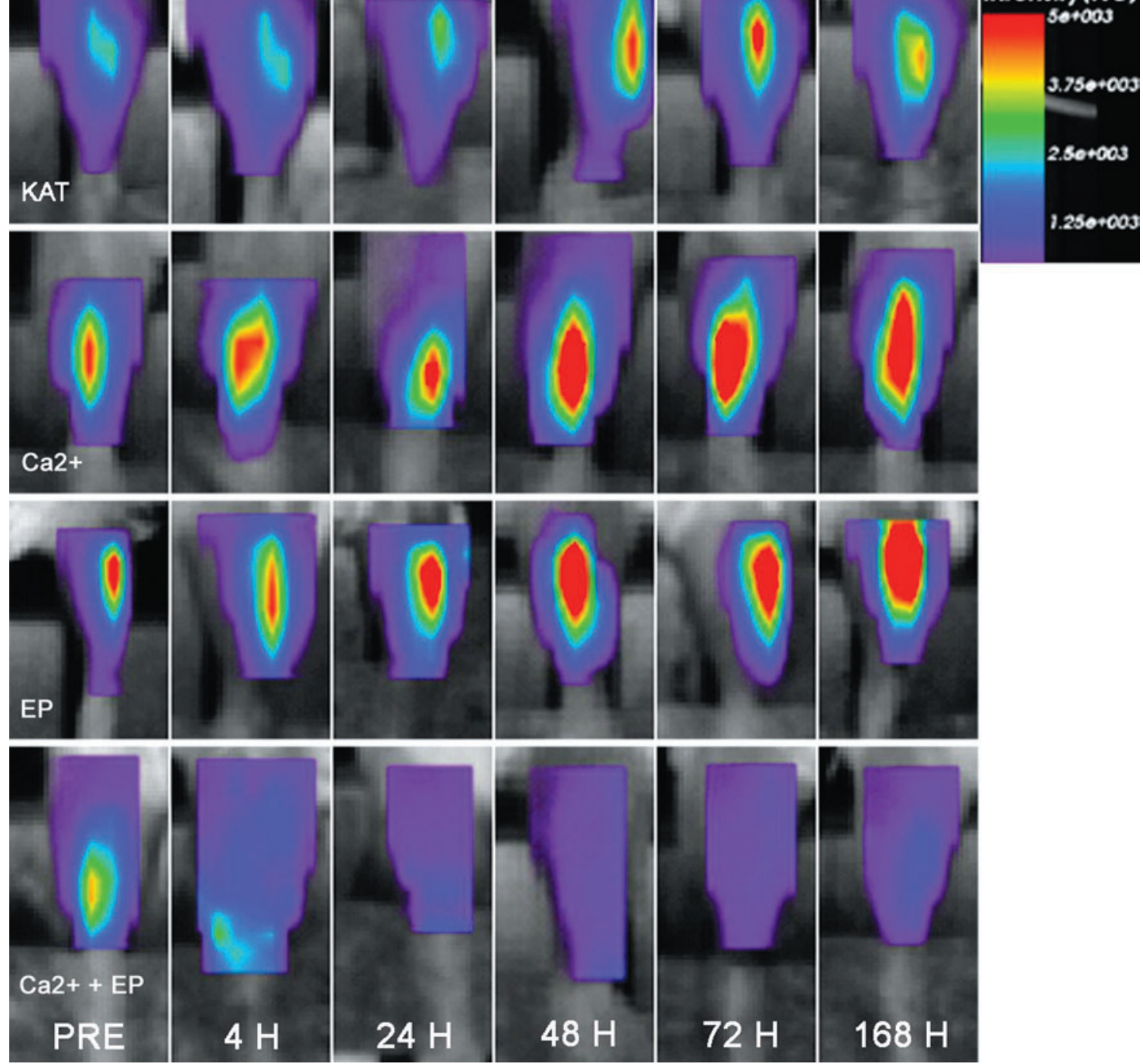

FIG. 2. In vivo imaging of Katushka (Kat) expression following $\mathrm{Ca}^{2+}$ electrotransfer. Time-domain in vivo imaging of Kat expression in muscles prior to and 4, 24, 48, 72, and $168 \mathrm{hr}$ after $\mathrm{Ca}^{2+}$ electrotransfer. Four days prior to Ca ${ }^{2+}$ electrotransfer all muscles were transfected with Kat. The pictures depicted a representative mouse (same mouse at all six time points) for the four conditions: Kat (untreated); $\mathrm{Ca}^{2+}\left(20 \mu \mathrm{l}\right.$ of $\left.\mathrm{Ca}^{2+}, 168 \mathrm{mM}\right)$; EP (eight high voltage [HV] pulses of $\left.1000 \mathrm{~V} / \mathrm{cm}\right)$; and Ca-EP $\left(\mathrm{Ca}{ }^{2+}\right.$ electrotransfer with $20 \mu \mathrm{l}$ of $\mathrm{Ca}^{2+}, 168 \mathrm{mM}$ ) followed by eight $\mathrm{HV}$ pulses of $\left.1000 \mathrm{~V} / \mathrm{cm}\right)$. Each group consisted of eight mice.

time points (Fig. 3). The half-life of Kat in aqueous solutions is $20 \mathrm{~min}$ (Shcherbo et al., 2007), thus our results indicate that expression of Kat is immediately turned off at the time of $\mathrm{Ca}^{2+}$ electrotransfer. There was no significant difference between the electroporated, $\mathrm{Ca}^{2+}$ injected, and control group, and all three groups peaked in fluorescence intensity $72 \mathrm{hr}$ after $\mathrm{Ca}^{2+}$ electrotransfer (thus 7 days after Kat electrotransfer). This is consistent with previous reports, showing that Kat expression peaks 1 week after Kat electrotransfer (Hojman et al., 2009).

To determine the stability of the fluorescence signal, lifetime, which is an intrinsic property of the fluorochrome, was measured. For Kat, the lifetime is 2.1 nsec. In the $\mathrm{Ca}^{2+}$ electrotransfer treated muscles, the lifetime decreased dramatically, and was significantly reduced 24 hours after $\mathrm{Ca}^{2+}$ electrotransfer and at the following time points $(p<0.001)$ (Fig. 3B), indicating that the integrity of the Kat molecule is decreasing. At $48 \mathrm{hr}$, the lifetime had reached the level measured in untransfected control muscles (data not shown), indicating that the Kat expression was completely eliminated. No reductions in the lifetime signal in the electroporated, $\mathrm{Ca}^{2+}$ injected, or control groups were observed, consistent with the finding that Kat expression remains stable in these muscles.

\section{Termination of EPO expression}

In addition to the termination of a locally expressed transgene, it was investigated if $\mathrm{Ca}^{2+}$ electrotransfer could also terminate expression of systemically secreted transgenic proteins, such as EPO. EPO electrotransfer with $2 \mu \mathrm{g}$ to one rat tibialis cranialis muscle resulted in significant increases in serum EPO (EPO: $460.4 \pm 123.5 \mathrm{pg} / \mathrm{ml}$, control: $27.5 \pm 2.2 \mathrm{pg}$ / $\mathrm{ml}, \quad n=7-14, \quad p<0.05)$ and hemoglobin levels (EPO: $9.6 \pm 0.6 \mathrm{mmol} / \mathrm{L}, \quad$ control: $\quad 7.4 \pm 0.3 \mathrm{mmol} / \mathrm{L}, \quad n=7-14$, 

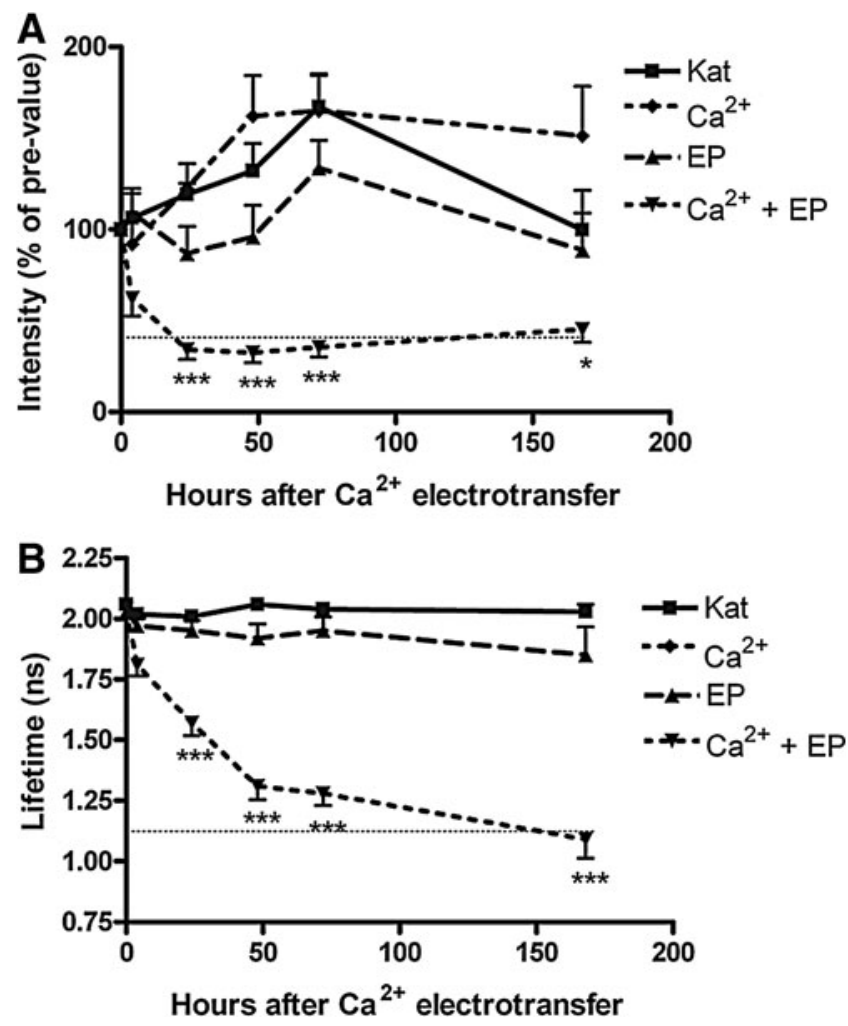

FIG. 3. Fluorescence intensity and lifetime of Kat expression. Fluorescent signals from Fig. 2 were analyzed for (A) fluorescent intensity (expressed as \% of pre value) and (B) mean lifetime of the fluorescent signals (nsec). Statistical significance was tested by two-way ANOVA with ad hoc Bonferroni $t$-tests. $N=8,{ }^{*} p<0.05$ and ${ }^{* * *} p<0.001$. The dotted line in (A) indicates background fluorescent intensity in untransfected muscles.

$p<0.05$ ) as previously described (Hojman et al., 2007b). Fourteen days after EPO electrotransfer, half of the EPOtransfected muscles were treated with $\mathrm{Ca}^{2+}$ electrotransfer, while the rest remained untreated. As depicted in Fig. 4A, the serum EPO levels decreased rapidly and were reduced $46 \%$ within $4 \mathrm{hr}$ of termination compared with animals not receiving $\mathrm{Ca}^{2+}$ electrotransfer $(p<0.05)$. The half-life of serum EPO is $3-7 \mathrm{hr}$ (Gothelf et al., 2010). After $48 \mathrm{hr}$, the serum EPO levels in the $\mathrm{Ca}^{2+}$ electrotransfer-treated animals $(37.2 \pm 6.3 \mathrm{pg} / \mathrm{ml}, n=7)$ were at the level of control animals $(25.0 \pm 0.1 \mathrm{pg} / \mathrm{ml})$. In continuation, the hemoglobin levels in the $\mathrm{Ca}^{2+}$ electrotransfer treated rats returned to control levels 2 weeks after $\mathrm{Ca}^{2+}$ electrotransfer $(p<0.001$, Fig. 4B). At $4 \mathrm{hr}$, an initial increase in serum EPO levels was observed for both control groups (control and EPO). This increase is associated with hypoxia during the anesthesia, as has been reported previously (Gothelf et al., 2009).

Similarly, serum EPO levels in mice were determined after $\mathrm{Ca}^{2+}$ electrotransfer, electroporation, $\mathrm{Ca}^{2+}$ injection, or no intervention, respectively. As shown in rats, $\mathrm{Ca}^{2+}$ electrotransfer completely eliminated EPO expression, and serum EPO levels returned to baseline within 2 weeks. Treatment with electroporation or $\mathrm{Ca}^{2+}$ injection did not have any effects on serum EPO and hemoglobin levels in mice (Fig. 4C).
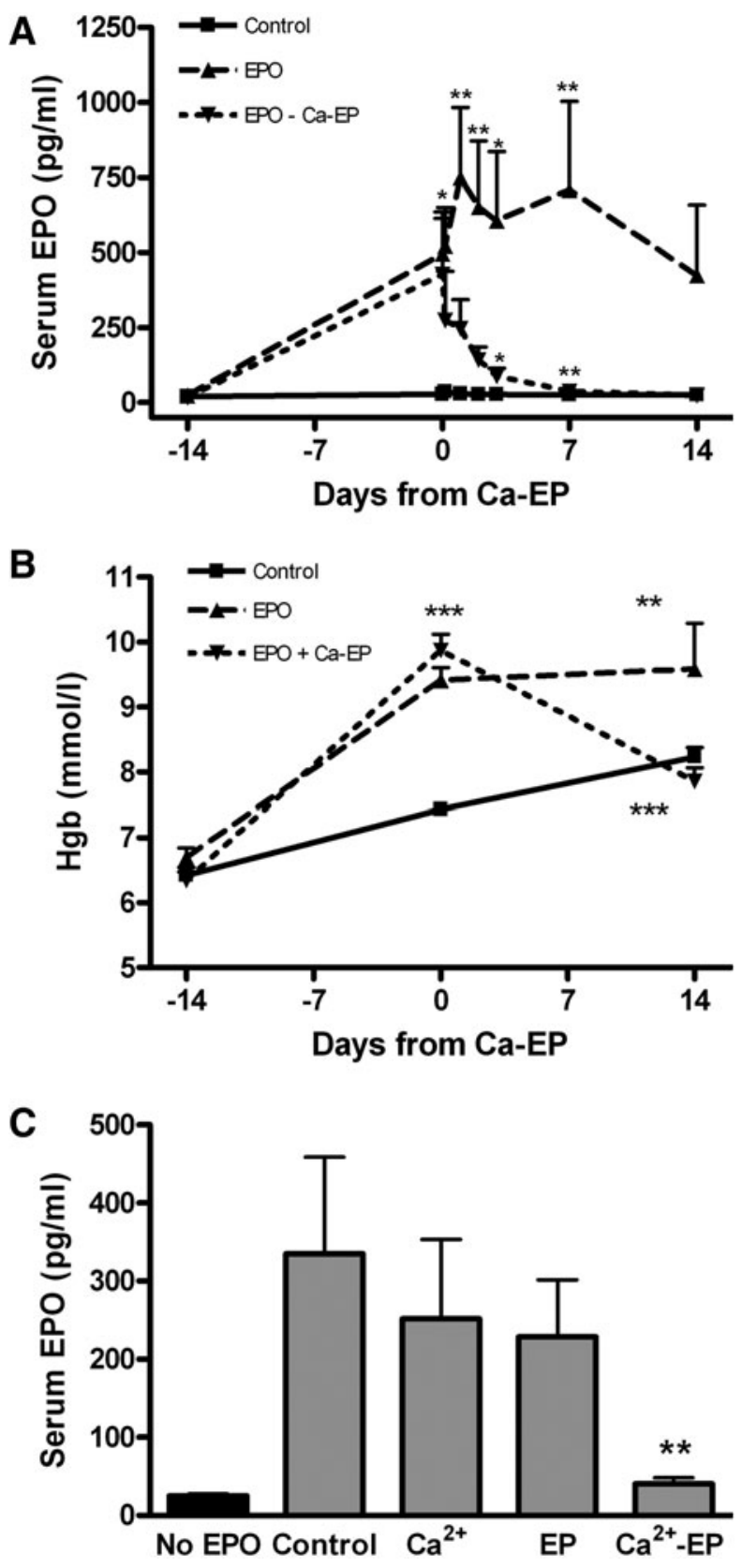

FIG. 4. Termination of muscular erythropoietin (EPO) expression. Blood samples were taken prior to; 4, 24, 48, 72 hr; and 1 and 2 weeks after $\mathrm{Ca}^{2+}$ electrotransfer for the determination of hemoglobin and serum EPO levels. (A) Serum $\mathrm{EPO}(\mathrm{pg} / \mathrm{ml}$ ) in rats: Control (untransfected rats), EPO (EPO transfected rats), and $\mathrm{EPO}+\mathrm{Ca}-\mathrm{EP}$ (EPO transfected rats with $\mathrm{Ca}^{2+}$ electrotransfer). (B) Hemoglobin levels in the rats from (A). (C) Serum EPO levels $(\mathrm{pg} / \mathrm{ml})$ in mice 2 weeks after $\mathrm{Ca}^{2+}$ electrotransfer, $\mathrm{EP}, \mathrm{Ca}^{2+}$ injection, or no intervention, respectively. Statistical significance was tested by two-way ANOVA with ad hoc Bonferroni $t$-tests. $N=8$, ${ }^{*} p<0.05$ and ${ }^{* * *} p<0.001$.

\section{Safety of the procedure}

Four hours after $\mathrm{Ca}^{2+}$ electrotransfer, the $\mathrm{Ca}^{2+}$ electrotransfer treated legs were markedly swollen compared to the control legs. A slight swelling of the electroporated legs was 

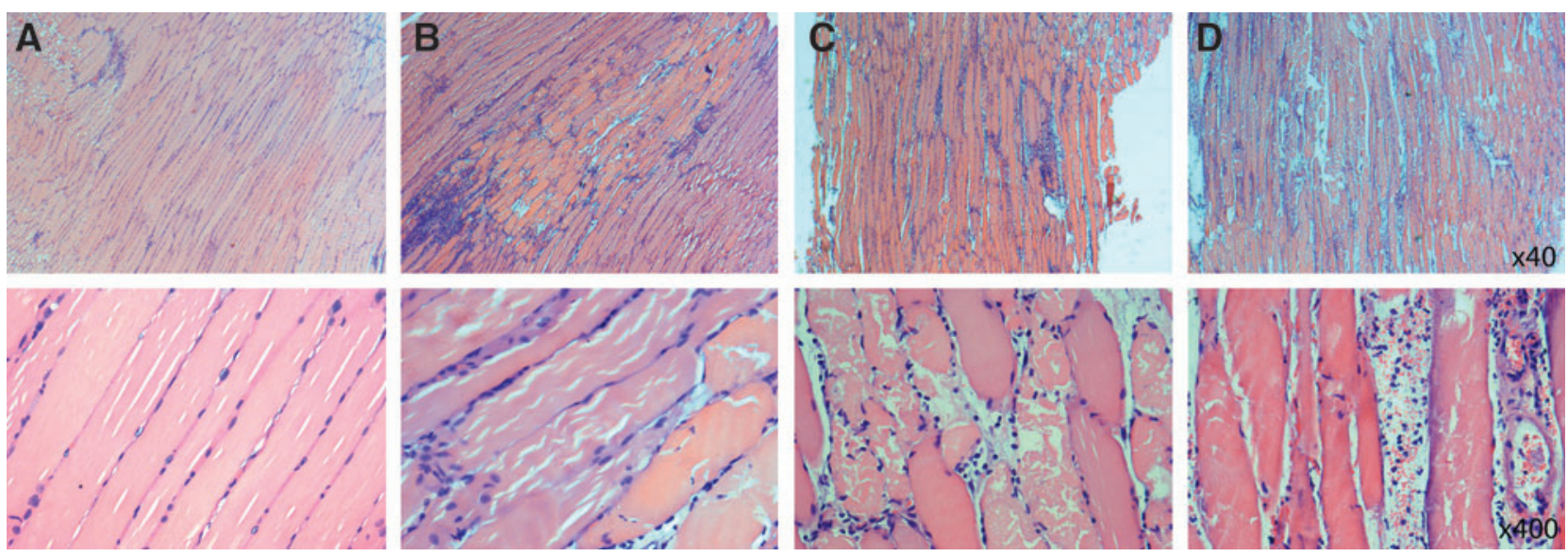

FIG. 5. Histological analysis of muscle after $\mathrm{Ca}^{2+}$ electrotransfer. Twenty-four hours post treatment with Ca ${ }^{2+}$ injection only, EP only, $\mathrm{Ca}^{2+}$ electrotransfer, or no intervention, respectively; muscles were taken for histological examination. (A) No intervention, (B) $\mathrm{Ca}^{2+}$ injection only, (C) $\mathrm{EP}$ only, and (D) $\mathrm{Ca}^{2+}$ electrotransfer. All photos: hematoxylin and eosin staining, $\times 40 / 400$ magnification.

also observed. To assess functional impairments, motor and reflex function were tested $24 \mathrm{hr}$ after $\mathrm{Ca}^{2+}$ electrotransfer in the treated muscles as previously described (Hojman et al., 2007c). No impairments in running and grabbing behavior were observed for any of the treatments (data not shown). Testing at $4 \mathrm{hr}$ could not be performed because the mice were still affected by the anesthesia.

Histological analysis was performed on routine $2-\mu \mathrm{m}$ sections of formalin-fixed, paraffin-embedded mouse muscles, isolated from the mice $24 \mathrm{hr}$ after $\mathrm{Ca}^{2+}$ electrotransfer and stained with hematoxylin-eosin (HE). Evaluation was blinded and the findings showed four patterns (Fig. 5): (1) normal morphology in control muscles, 2) normal muscle morphology with only one focus of coagulation necrosis and mixed inflammation in the $\mathrm{Ca}^{2+}$-injected muscles, 3) diffuse mixed inflammation and diffuse coagulation necrosis in the electroporated muscles, and 4) diffuse mixed inflammation, diffuse coagulation necrosis, and extravasation of red blood cells in the $\mathrm{Ca}^{2+}$ EP-treated muscles.

Investigation of mouse muscles 14 days after treatment showed a variety of pathological changes ranging from small to larger foci of necrosis and inflammation. Overall, the changes were more subtle and the main part of the muscle fibers had regained striation. One muscle treated with $\mathrm{Ca}^{2+}$ electrotransfer showed a large focal area with changes of probable necrosis that could not be characterized further. This area was also visible by eye when removing the muscle. The focal effects might be explained by differences in muscle fiber diameter and orientation. Surprisingly, two muscles receiving no treatment showed slightly diffuse inflammation and reactive changes. In contrast, muscles receiving $\mathrm{Ca}^{2+}$ electrotransfer showed clear signs of regeneration.

\section{Discussion}

In this study, we show that loading muscles expressing transgenic proteins with $\mathrm{Ca}^{2+}$ completely abolished transgene expression and production. The elimination of transgene expression was already significant $4 \mathrm{hr}$ after $\mathrm{Ca}^{2+}$ electrotransfer and was complete at $48 \mathrm{hr}$. No impairments in running and grabbing behavior were observed, although major histological changes were seen. At 14 days after treatment, the muscles showed clear signs of recovery including regaining muscle fiber striation. Thus, this method represents a safe and efficient way of terminating transgene expression.

\section{Clinical perspective for $\mathrm{Ca}^{2+}$ electrotransfer}

As gene electrotransfer to muscle tissue is increasingly used in clinical trials (Daud et al., 2008; Sallberg et al., 2009; Hojman, 2010), solutions for control of expression have been investigated. A specific issue is having an emergency shut-off strategy available, and precise and quick termination of transgene expression is especially highly warranted. Gene therapy with viral or chemical vectors transfect disperse tissues, thus precise localization of the site of transfection is not possible. In contrast, physical transfection methods like electrotransfer offer precise positioning of the transfected area due to the intrinsic properties of the transfection methods, i.e., transfer only takes place in the tissue encompassed by the electrodes delivering the electric field. Thus in this case, it is possible to relocate the transfected area for post-transfection interventions, e.g., in order to terminate the transgenic signal. Inducible promoter systems have been proposed to control gene expression. Currently no inducible promoter systems have been approved for use in the clinical setting because concerns like the inducer drugs, which in the current systems are either antibiotics or hormone analogues, exist. Furthermore, although extensive efforts have been put into optimizing these inducer systems, leakage in gene expression does still occur, and withdrawal of the exogenous inducer does not therefore necessarily result in complete elimination of the transgene expression. In contrast, we foresee that $\mathrm{Ca}^{2+}$ electrotransfer can be introduced fairly easily into the clinic because both application of electric pulses and Calcium-Sandoz is routinely used in the clinical setting. The set-up for $\mathrm{Ca}^{2+}$ electrotransfer will mimic DNA electrotransfer or electrochemotherapy regimens, and thus would be directly applicable in facilities that are already applying these procedures.

Electroporation has been used extensively in the clinic for electrochemotherapy for cancer patients (Heller et al., 1998; 
Gothelf et al., 2003; Marty et al., 2006; Mir et al., 2006). Thus the clinical feasibility of electrotransfer-based techniques is well established. In this study, we combined electrotransfer with $\mathrm{Ca}^{2+}$. Calcium is an endogenous ion with little toxic effect; in fact the only foreseeable side effect of this molecule is hypercalcemia. For $\mathrm{Ca}^{2+}$ electrotransfer in rats, we injected $30 \mu \mathrm{l}$ of $168 \mathrm{mM} \mathrm{Ca}^{2+}$, which equals $5 \mu \mathrm{mol}$ and thus yields a $27 \%$ increase in plasma $\mathrm{Ca}^{2+}$ concentration if all $\mathrm{Ca}^{2+}$ is recovered in the blood. Yet the rats did not show any signs of adverse effects or discomfort. In patients, far lower increases in plasma $\mathrm{Ca}^{2+}$ concentrations are foreseen. Current clinical trials with muscle electrotransfer have treated muscle volumes of a maximum of $1 \mathrm{~cm}^{3}$, with the muscle fibers transversing this area transfected in their full length. In this case, one treatment of $\mathrm{Ca}^{2+}$ electrotransfer $(100 \mu$ l of $168 \mathrm{mM})$ will induce a potential $1 \%$ increase in plasma $\mathrm{Ca}^{2+}$ concentration.

\section{Pulse parameters for $\mathrm{Ca}^{2+}$ electrotransfer}

In this study, we used two different kinds of pulse regimens for DNA and $\mathrm{Ca}^{2+}$ electrotransfer, respectively. Previous studies have shown that electrotransfer of small molecules and plasmid DNA relies on different mechanisms. Small molecules and ions depend on simple diffusion through the permeabilized membrane, and short ( $\mu$ sec) pulses of high amplitude result in the best delivery. Because $\mathrm{Ca}^{2+}$ is an ion and has a very large concentration gradient, we chose this pulse regimen. This mechanism is also explored in the clinical electrochemotherapy protocols of transfer of drug molecules, e.g., bleomycin (Mir et al., 2006). The large and highly anionic plasmid DNA molecule, however, does not enter cells through simple diffusion. Instead, electrotransfer of plasmid DNA relies on a line of events including (1) electrophoretic migration of DNA towards the plasma membrane, (2) DNA accumulation and transport over the plasma membrane, and (3) intracellular trafficking of the DNA to the nucleus (Favard et al., 2007). For this process to occur, longer electric pulses (milliseconds) are needed (Lucas and Heller, 2001), and thus we have chosen a pulse regimen of a HV and a LV pulse, which has previously been shown to give good transfection efficacy in muscles (Andre et al., 2008).

\section{Role of $\mathrm{Ca}^{2+}$ influx on muscle fitness and homeostasis}

$\mathrm{Ca}^{2+}$ plays an important role in muscles as a main regulatory and signaling molecule, and thus the concentration of $\mathrm{Ca}^{2+}$ in the cytosol is tightly controlled and is maintained at $50-100 \mathrm{nM}$ in the resting state (Berchtold et al., 2010). This is in sharp contrast to the extracellular fluid, where the $\mathrm{Ca}^{2+}$ concentration without $\mathrm{Ca}^{2+}$ injection is $1.3 \mathrm{mM}$. Thus the concentration gradient for $\mathrm{Ca}^{2+}$ across the membrane is very high. Permeabilization of the membrane may lead to massive influx of $\mathrm{Ca}^{2+}$ (Gissel, 2010), which may lead to $\mathrm{Ca}^{2+}$ overload defined as excessive accumulation of $\mathrm{Ca}^{2+}$ in the muscle cell, resulting in loss of control of intracellular free $\mathrm{Ca}^{2+}$. This, in turn, may lead to activation of calpains and possibly PLA , $_{2}$ increased reactive oxygen species production and mitochondrial $\mathrm{Ca}^{2+}$ overload (Nethery et al., 2000; Goll et al., 2010; Sandercock and Mitchell, 2010). All these effects will come into play together, resulting in proteolysis of intracellular components, disruption membrane integrity, and loss of ATP production. This may start a vicious cycle of continuing cell damage and $\mathrm{Ca}^{2+}$ influx and eventually result in cell death (Cerella et al., 2010). Our results indicate that the $\mathrm{Ca}^{2+}$ electrotransfer results in $\mathrm{Ca}^{2+}$ overloading and thus the vicious cycle, resulting in elimination of the transfected fibers.

\section{Conclusion}

Gene therapy is rapidly expanding to clinical use, and safe and efficient methods for termination of transgene expression are warranted. In this study, we provide a simple and efficient way of quickly eliminating all transgene expression in muscles by $\mathrm{Ca}^{2+}$ electrotransfer. The massive influx of $\mathrm{Ca}^{2+}$ during $\mathrm{Ca}^{2+}$ electrotransfer disrupts normal cell function, eliminating transgene expression, and induces marked histological changes. This procedure represents a feasible way for quick elimination of transgene expression in emergency situations since (1) only a small volume of muscle will be affected in patients, (2) $\mathrm{Ca}^{2+}$ is a nontoxic molecule, when it is not introduced to cells by electrotransfer, and (3) muscles have a high capacity of regeneration and normal muscle morphology will be restored within 2 weeks.

\section{Acknowledgments}

Ruth Rousing, Hanne Villumsen, Lone Boye, Lone Christensen, and Vibeke Uhre are acknowledged for their technical assistance. $\mathrm{PH}$ is supported by a grant from the Danish Medical Council, IS is supported by a grant from the Danish Cancer Foundation, HGH is supported by a grant from the Lundbeck foundation, and JG is a research fellow of the Royal Swedish Academy of Science supported by the Acta Oncologica Foundation.

\section{Author Disclosure Statement}

All authors declare they have no conflicts of interest.

\section{References}

Aihara, H., and Miyazaki, J. (1998). Gene transfer into muscle by electroporation in vivo. Nat. Biotechnol. 16, 867-870.

Andre, F., Gehl, J., Sersa, G., et al. (2008). Efficiency of high and low voltage pulse combinations for gene electrotransfer in muscle, liver, tumor and skin. Hum. Gene Ther. 19, 1261-1271.

Bainbridge, J., Smith, A.J., Barker, S.S., et al. (2008). Effect of gene therapy on visual function in Leber's congenital amaurosis. $\mathrm{N}$. Engl. J. Med. 358, 2231-2239.

Berchtold, M.W., Brinkmeier, H., and Muntener, M. (2010). Calcium ion in skeletal muscle: its crucial role for muscle function, plasticity, and disease. Physiol. Rev. 80, 1215-1265.

Bettan, M., Emmanuel, F., Darteil, R., et al. (2000). High-level protein secretion into blood circulation after electric pulsemediated gene transfer into skeletal muscle. Mol. Ther. 2, 204-210.

Bier, M., Hammer, S.M., Canaday, D.J., and Lee, R.C. (1999). Kinetics of sealing for transient electropores in isolated mammalian skeletal muscle cells. Bioelectromagnetics 20, 194-201.

Cerella, C., Diederich, M., and Ghibelli, L. (2010). The dual role of calcium as messenger and stressor in cell damage, death, and survival. Int. J. Cell Biol. 2010:546163.

Clark, K.M., Bindoff, L.A., Lighttowlers, R.N., et al. (1997). Reversal of a mitochondrial, DNA defect in human skeletal muscle. Nat. Genet. 16, 222-224.

Daud, A.I., DeConti, R.C., Andrews, S., et al. (2008). Phase I Trial of Interleukin-12 Plasmid Electroporation in Patients With Metastatic Melanoma. J. Clin. Oncol. 26, 5896-5903. 
Draghia-Akli, R., Ellis, K.M., Hill, L.A., et al. (2003). Highefficiency growth hormone-releasing hormone plasmid vector administration into skeletal muscle mediated by electroporation in pigs. FASEB J. 17, 526-528.

Fattori, E., Cappelletti, M., Zampaglione, I., et al. (2005). Gene electro-transfer of an improved erythropoietin plasmid in mice and non-human primates. J. Gene Med. 7, 228-236.

Favard, C., Dean, D.S., and Rols, M.P. (2007). Electrotransfer as a non viral method of gene delivery. Curr. Gene Ther. 7, 67-77.

Gehl, J. (2003). Electroporation: theory and methods, perspectives for drug delivery, gene therapy and research. Acta Physiol. Scand. 177, 437-447.

Gehl, J., Skovsgaard, T., and Mir, L.M. (2002). Vascular reactions to in vivo electroporation: characterization and consequences for drug and gene delivery. Biochim. Biophys. Acta 1569, 5158.

Gissel, H. (2010). Effects of varying pulse parameters on ion homeostasis, cellular integrity, and force following electroporation of rat muscle in vivo. Am. J. Physiol. Regul. Integr. Comp. Physiol. 298:R918-R929.

Goll, D.E., Thompson, V.F., Li, H., et al. (2010). The calpain system. Physiol. Rev. 83, 731-801.

Gossen, M., Freundlieb, S., Bender, G., et al. (1995). Transcriptional activation by tetracyclines in mammalian cells. Science 268, 1766-1769.

Gothelf, A., Eriksen, J., Hojman, P., and Gehl, J. (2010). Duration and level of transgene expression after gene electrotransfer to skin in mice. Gene Ther. 17, 839-845.

Gothelf, A., Hojman, P., and Gehl, J. (2009). Change in hemoglobin levels due to anesthesia in mice: an important confounder in studies on hematopoietic drugs. Biol. Proc. Online $11,325-330$.

Gothelf, A., Mir, L.M., and Gehl, J. (2003). Electrochemotherapy: results of cancer treatment using enhanced delivery of bleomycin by electroporation. Cancer Treat. Rev. 29, 371-387.

Heller, L.C., and Heller, R. (2006). In vivo electroporation for gene therapy. Hum. Gene Ther. 17, 890-897.

Heller, R., Jaroszeski, M.J., Reintgen, D.S., et al. (1998). Treatment of cutaneous and subcutaneous tumors with electrochemotherapy using intralesional bleomycin. Cancer 83, 148-157.

Hojman, P. (2010). Basic principles and clinical advancements of muscle electrotransfer. Curr. Gene Ther. 10:128-138.

Hojman, P., Eriksen, J., and Gehl, J. (2007a). Tet-On induction with doxycycline after gene transfer in mice: sweetening of drinking water is not a good idea. Anim. Biotechnol. 18, 183188.

Hojman, P., Eriksen, J., and Gehl, J. (2009). In vivo imaging of far-red fluorescent proteins after, DNA electrotransfer to muscle tissue. Biol. Prod. Online 11, 253-262.

Hojman, P., Gissel, H., Andre, F., et al. (2008). Physiological effects of high and low voltage pulse combinations for gene electrotransfer in muscle. Hum. Gene Ther. 19, 1249-1261.

Hojman, P., Gissel, H., and Gehl, J. (2007b). Sensitive and precise regulation of haemoglobin after gene transfer of erythropoietin to muscle tissue using electroporation. Gene Ther. 14, 950959.

Hojman, P., Zibert, J., Gissel, H., et al. (2007c). Gene expression profiles in skeletal muscle after gene electrotransfer. BMC Mol. Biol. 8:56.

Kohn, D. (2010). Update on gene therapy for immunodeficiencies. Clin. Immunol. 135, 247-254.

Lu, Q.L., Bou-Gharios, G., and Partridge, T.A. (2003). Non-viral gene delivery in skeletal muscle: a protein factory. Gene Ther. $10,131-142$.
Lucas, M.L., and Heller, R. (2001). Immunomodulation by electrically enhanced delivery of plasmid, DNA encoding, IL-12 to murine skeletal muscle. Mol. Ther. 3, 47-53.

Maguire, A.M., Simonelli, F., Pierce, E.A., et al. (2008). Safety and efficacy of gene transfer for Leber's congenital amaurosis. N. Engl. J. Med. 358, 2240-2248.

Marty, M., Sersa, G., Garbay, J.R., et al. (2006). Electrochemotherapy - an easy, highly effective and safe treatment of cutaneous and subcutaneous metastases: results of ESOPE (European Standard Operating Procedures of Electrochemotherapy) study. Eur. J. Cancer Suppl. 4, 3-13.

Mathiesen, I. (1999). Electropermeabilisation of skeletal muscle enhances gene transfer in vivo. Gene Ther. 6, 508-514.

Mir, L.M., Bureau, M.F., Gehl, J., et al. (1999). High-efficiency gene transfer into skeletal muscle mediated by electric pulses. Proc. Natl. Acad. Sci. U. S. A. 96, 4262-4267.

Mir, L.M., Gehl, J., Sersa, G., et al. (2006). Standard operating procedures of the electrochemotherapy: Instructions for the use of bleomycin or cisplatin administered either systemically or locally and electric pulses delivered by the Cliniporator ${ }^{\mathrm{TM}}$ by means of invasive or non-invasive electrodes. Eur. J. Cancer Suppl. 4, 14-25.

Nethery, D., Callahan, L.A., Stofan, D., et al. (2000). PLA2 dependence of diaphragm mitochondrial formation of reactive oxygen species. J. Appl. Physiol. 89, 72-80.

Nordstrom, J.N. (2003). The antiprogestin-dependent GeneSwitch ${ }^{\circledR}$ system for regulated gene therapy. Steroids 68, 10851094.

Sallberg, M., Frelin, L., Diepolder, H.M., et al. (2009). Activation of $\mathrm{T}$ cell responses and reductions in the viral load following therapeutic vaccination using naked DNA delivered by in vivo electroporation in patients with chronic hepatitis $\mathrm{C}$. [Abstract.] Mol. Ther. 17(1), S15.

Sandercock, D.A., and Mitchell, M.A. (2010). Myopathy in broiler chickens: a role for $\mathrm{Ca}(2+)$-activated phospholipase A2? Poult. Sci. 82, 1307-1312.

Shcherbo, D., Merzlyak, E.M., Chepurnykh, T.V., et al. (2007). Bright far-red fluorescent protein for whole-body imaging. Nat. Methods 4, 741-746.

Address correspondence to: Dr. Julie Gehl

Department of Oncology 54B1 Copenhagen University Hospital Herlev Herlev Ringvej 75

DK-2730

Denmark

E-mail: juge@heh.regionh.dk

Dr. Hanne Gissel Department of Physiology and Biophysics University of Aarhus

Ole Worms Alle 1160

DK-8000 Aarhus

Denmark

E-mail: hgh@fi.au.dk

Received for publication October 28, 2010;

accepted after revision February 10, 2011.

Published online: February 11, 2011. 